\title{
Effect of Media Violence on Aggression, Attitude and Emotions of Adults
}

\author{
Dr. Soni Kewalramani ${ }^{1}$, Ms. Alka Pandey ${ }^{2}$
}

Keywords: Media, Violence, Aggression, Attitude, Emotions, Adults.

Current scenario of crime rate in India is increasing day by day. Increasing of crime rate in India depicts an extremely poor condition of our country law and order. According to national crime bureau (NCRB), ministry of home affairs, Government of India, during 2010, a total of 67,50,748 cognizable crimes comprising 22,24,831 Indian Panel Code crimes (IPC) crimes and 45,25,917 special and local laws( SLL) crimes were reported that there was an increase of $1.1 \%$ over 2009 (66,75,217). According to Indian Penal Code crime rate has increased by 3.9\% over 2009. Crime rate from 1953-2011 shows that crimes such as dacoity and burglary/house breaking has been decreased by 59 years but crimes such as murdered, rape, kidnapping and abduction, robbery and riots have been increasing day by day. Murder has increased by 250.0\% (from 9,802 in 1953 to 34,305 in 2011), rape 873.3\% (from 2,487 in 1971 to 24,206 in 2011), kidnapping and abduction by $749 \%$ (from 5,261 in 1953 to 44,664 in 2011) and riots by $233.7 \%$ (from 20,529 in 1953 to 68,500 in 2011).

In the recent year society has seen a notable increase in the rate of youth crime. Everyone can easily see on the headlines of newspapers like "youth involve in chain snatching" or "Youth involve in kidnapping of businessman son", college girl friend beaten up by gang of youth in Uttar Pradesh". These shocking news comes as a headlines of a newspaper on a daily bases. According to the National Crime Records Bureau, $44 \%$ of the arrested criminals belong to the age group of 10 to 30 years, which is the youth (as per the 2011 statistics). The crime rate has been increasing drastically which range from thefts to kidnapping, murders, rape, and sex scandals involve such people. From the above discussion it has been found that youth and crime is not a new phenomenon. Society has seen both in past as well as in present where youth crime rate increases very drastically. The cases found like murders, theft, sexual involvement, robbery, attempt to murder, kidnapping, cheating etc. All these are the crimes done by the youth.

In the further studies there will be the discussion on the crimes, types of crimes, causes of crimes, about how media effects the youths and about the reports on youth violence and more on.

\footnotetext{
${ }^{1}$ Assistant Professor, AIBAS, Amity University Uttar Pradesh, Lucknow Campus

${ }^{2}$ AIBAS, Amity University Uttar Pradesh, Lucknow Campus

*Responding Author

(C) 2016 I S Kewalramani, A Pandey; licensee IJIP. This is an Open Access Research distributed under the terms of the Creative Commons Attribution License (http://creativecommons.org/licenses/by/2.0), which permits unrestricted use, distribution, and reproduction in any Medium, provided the original work is properly cited.
} 


\section{What is crime?}

A crime is an illegal act that is against law for which someone can be punished by the government.

i) The word 'crime' is origin of viz ; 'crimean' which means charge or 'offence' crime is a social fact.

ii) According to Austin crime is an act or omission which the law punishes.

iii) According to Sir William Black tone defined crime as 'an act committed or omitted in violation of public law forbidding or commanding it'.

iv) According to Blackstone crime is an act omitted or committed, in violation of a public law, either forbidding or commanding it, a breach or violation of some public right or duty to due to a whole community considered as a community.

\section{Types of crime:}

As we all know crime is an act which is against law and order. Thus there are various types of crime such as:

\section{i) Crimes against persons:}

It is also known as personal crimes which include, rape, robbery, murders, aggravated assaults, kidnapping, abducting etc.

In the United States personal crimes are basically related with the young, urban, poor, and racial minority people who commit all these types of crime more than all other types of people.

\section{ii) Crimes against property:}

These types of crime are those crimes which include theft of property without harming the body, such as robbery, burglary, auto theft, and arson.

Like the personal crimes these crimes are also committed by young, poor, racial minorities and urban people than others.

iii) Crime against morality:

It is also known as victimless crimes as there is no complaint or victim. Illegal gambling, illegal drug use and prostitution come under this type of crimes.

iv) White-collar crime:

These are the crimes which are committed by the people of high social status in context to their occupation. Examples are embezzling (of money from one's employer), tax evasion, insider training and other violation of income tax. These types of are generally the least investigated and least prosecuted.

v) Organised crime:

It is the crimes which are committed by the structured groups typically which involves the distribution of illegal goods and services to others. Examples are drug trade, illegal gambling, prostitution, money launderings, or weapons smuggling. 


\section{Crimes which are being committed more by young adolescents:}

According to the report by Global Youth Justice in 'Making the Time for Juvenile Crime' there are some crimes which are mostly committed by young adolescents:

(i) Theft/ Larceny-

It includes shop lifting, stealing a bicycle, stealing from backpacks and lockers.

(ii) Alcohol offenses-

In this type of crime under purchase or possession, underage consumption of alcohol, providing alcohol to underage person, possessing an open container in public/cars.

(iii) Disorderly conduct-

It includes fighting in a public place, cursing at a teacher, flashing, mooning and indecent exposure.

(iv) Simple assault or battery-

It includes bullying when it amount to assault, child/parent physical disagreements, shoving or pushing a person.

(v) Possession of marijuana-

It includes Possessing small amounts of marijuana in a public place.

(vi) Tobacco offenses-

It includes illegally purchasing tobacco, chewing or smoking tobacco at school, providing or enabling youth to use tobacco.

(vii) Traffic violations-

It includes speeding or failing to yield, not wearing a seat belt, riding in the back of a picking truck.

(viii) Harassment-

It includes bullying, making telephone calls without good reason, insulting or provoking a disorderly response.

\section{Causes of crime:}

As the technologies are developing day by day and due to this the urban cities are gradually developing in terms of better lifestyles, facilities, income and standard of living, people are increasingly migrating towards the urban areas which causes misbalance in fulfilment of basic needs or resources caused by overpopulation. This imbalance lead to the various competition, insecurity or rivalry among people which rises the crime in urban areas and the biggest irony is that cities or urban areas are becoming the 'hub' of crime and violence which are increasing drastically day by day. These raise of crime in Indian cities may be due to the lack of adequate manpower, technology, equipment and a big reason is political will.

i) Poverty:

It is the main reason for committing the crime or in other words there is a close relationship between poverty and crime. Due to poverty the poor people are not able to live a standard life and are not able to fulfil their basic needs like food, shelter, 
clothes. Thus all this contributes or force them to commit crime. Poverty leads to commit crime like robbery as they find it a easier way to steal than the other ways.

ii) Lack of education:

It is also a great reason for committing a crime. As people are not well educated to find a job to work and earn money to fulfil their basic needs and requirement which leads them to for stealing money and committing a crime.

iii) Lack of unemployment:

It has been found that crime rates are higher due to unemployment, poverty. As unemployment refers to jobless which shows that the individual is not earning money due to which the person is not able to live a standard life or fulfil his or her family members basic needs and this forces the individual to steal the money and commits a crime.

iv) Family factors:

It is also an important factor for increasing of crime. If there will a poor parenting style it will definitely result in the raising of crime and this factor may include about how family members behave with each other, about how much attention is given and about attitudes.

"According to leading psychiatrist, the lack of adequate opportunities frustrates young people up to that extent that they use any method possible to attain success. Many cases like sexual assault and rapes go unreported due to which youngsters feel free to commit the same crime again and again. Even the judicial system shows leniency towards the accused.”

v) Peer group pressure:

In the life of a person peer group plays a very important role and it strongly influences a decision to commit crime. For example, young boys and girls who do not fit into expected standards of academic achievement or participate in sports or social programs can sometime become lost in the competition. Children of families who cannot afford adequate clothing or school supplies can also fall into the same trap.

Researchers believe these youth may abandon schoolmates in favour of criminal gangs, since membership in a gang earns respect and status in a different manner. In gangs antisocial behaviour and criminal activity earns respect and street credibility.

vi) Substance abuse:

Addiction to alcohol or some other substances are the major reason for committing of crime mainly by youth.

\section{Media}

Media effect on youth: In the recent year with the rise of mass media, media has a tremendous impact on our society. Let us take some examples that media has a great influence on us. Such as do you feel like to work in the serial as a lead role? , after watching a stunt in a movie do you feel like attempting it? , do you feel like play a role or being a detective after seeing a suspense movie? 
If your answer will be in 'YES' then it shows that media has a great influence on the society because media affect the way we think act and think. Thus question arises by many researchers, scholars, critics about the various effect media has on the society and as well as on the individual. These effects are very strong, has direct effect in the both positive and negative terms. The most important reason of media effect is mainly Television is affecting our society strongly in today’s scenario.

According to a report "Youth spends on an average four hours per day”.

Television is mainly influence the society through the stories about violence and this comes under the negative impact. As on the television, in today's scenario there are lots of serials based on the crime and violence, news, movies which shows the violence.

\section{Social learning theory:}

In violence we can say that social learning theory applies very extensively.

According to Albert Bandura's theory people learn the things by observing others. Observational learning could not occur unless cognitive processes were at work.

Social learning theory is the result of modelling oneself in response to the expectation of others. Behaviours and attitudes develop in response to reinforcement and encouragement from the people around us. Social learning theorists recognized that childhood experience is important; they also believe that the identity people acquire is formed more by the behaviours and attitudes of others.

According to social learning theory, people engage in crime because of their association with others who engage in crime. Their criminal behaviour is reinforced and they learn beliefs that are favourable to crime. For example- social learning theory plays important role in childhood and when a child sees that bullying, shop lifting, theft bring more amount of social power, money, and materialistic gain then automatically a child is more prone to undergo delinquent activity because of the reinforcement attach to it rather than punishments. Manifestation of this behaviour over and over again throughout his life leads to a learning of delinquent activity and preferences of peer and companions who helps him encouraging such activities .As a consequence, these individuals come to view crime as something that is desirable; at least justifiable in certain situations. It is done through association with exposure to others.

Social learning theory postulates that there are three mechanisms by which individuals learn to engage in crime: differential reinforcement, beliefs, and modelling.

(i) Differential reinforcement of crime:

Differential reinforcement of crime means that individuals can teach others to engage in crime by reinforcing and punishing certain behaviour. Crime is more 
likely to occur when it: 1) is frequently reinforced and infrequently punished. 2) Results in large amounts of reinforcement (such as money, social approval, or pleasure) and little punishment and 3) it is more likely to be reinforced than alternative behaviours.

(ii) Beliefs favourable to crime:

On top of reinforcing criminal behaviour, other individuals can also teach a person belief that is favourable to crime. A child learns from his childhood that behaviour that criminal behaviour reinforces more rather than punishment.

(iii) The imitation of criminal models:

Behaviour is not only a product of beliefs and reinforcements or punishments that individuals receive. It is also a product of the behaviour of others, especially if it is someone that individuals who witnesses someone they respect committing a crime, who is then reinforced for that crime is then more likely to commit a crime themselves.

\section{REVIEW OF LITERATURE}

In the present scenario the media violence has affected our young people and society very badly through various way in which television is the main source which has a great impact on our society today. Thus it is a very hot question and the researcher has found various researches, articles and debate has been done on this topic of media- crime serial effect.

The present chapter reports researches done in the area. Also media reports published time to time have been included in review of literature as they too through life on the current scenario. Also not many researchers have been done in this area as per the knowledge of the researcher.

Does the violence that children observe in television programs, movies and video games lead to behave aggressively?

This is a burning question of today, but it was also of great interest 50 years ago when psychologists led an experiment to determine how kids learn aggression through observation.

Bandura and his colleague's in1961 done an experiment 'Bobo Doll experiment' tested on 36 boys and 36 girls from the age between 3 to 6 years old. It was found that the children learn social behaviour such as aggression through the process of observation learning through watching the behaviour of another person.

This study has important implications for the effects of media violence on children”

\section{Crime and youth:}

A Research done on the 'Involvement of youth attitude in crime' in the year 2013 by Konch and Borbora. In this study 400 samples age group of 18-35 years in four jails of upper Assam - India. 
In this study it has been found that there are various risk factors which are responsible for committing crime like media impact, neighbourhood, poor economic condition etc all these factors are related to each other. Research work admitted that some television programme and motion pictures have now come to be blamed for many youth crimes. It has been found that the media plays another major role for the construction of attitudes, behaviour and physical changes of youth.

In 2012, the media violence commission of international society for research on aggression(ISRA) present a report that 'over the past 50 years, a large number of studies conducted around the world have shown that watching violent television, watching violent films, playing violent video games increases the likelihood for aggressive behaviour.

In 2009 policy statement on media violence, the American academy of paediatrics said, "Inclusive research shows that media violence can contribute to aggressive behaviour desensitization to violence, nightmares and fear of being harmed.

In another study 'Television violence and aggression: A Retrospective study in 2008' by Slotsve et al. In this study a survey was administered on the sample of 130 undergraduate students. In this it was found that participants who watched television programs that were violent in nature had thoughts of or would emulate the (violent) behaviour from the television programs. This correlation supports social learning theory.

In another study in the year 2006 American Medical Association present a study on ' Short- term and long-term effects of violent media on aggression in children and adults' the sample were children younger than 18 years and adults. It was found that short- term effects of violent media were greater for adults then for children whereas the long- term effects were greater for children than for adults. The result also showed that there were overall modest but significant effect sizes for exposure to media violence, on aggressive behaviours, aggressive thoughts, angry feelings, arousal level and helping behaviour.

In 2002, a report by the US Secret Service and the US department of education, which examined 39 incidents of targeted school shootings and school attacks from 1974 to 2000 in US, found that ' over half of the attackers demonstrated some interest in violence through movies, video games, books and other media.

In another meta-analysis by Paik and Constock in 'The effects of television violence on antisocial behaviour' conducted in 1994, examined 217 studies concerned with the impact of media violence on aggressive behaviour, with $85 \%$ of the sample in the age range 6-12 year. The authors concluded that there was a significant positive correlation between exposure to media violence and aggressive behaviours, regardless of age. 
From another cross-sectional studies by Paik and Constock in 'The effects of television violence on antisocial behaviour' in 1994 find that there is a positive correlation between media violence and various measures of aggression- for instance, attitudes and beliefs, behaviours and emotions such as anger. The effects of violent behaviours (such as assault and homicide), though, are rather smallest $(r=0.06)$.

According to a meta- analysis in 1991 by Wood, Wong and Chachere on' the effects of media violence on viewers' which involves 28 studies of children and adolescents exposed to media and observed in free social interaction, concluded that exposure to media violence increased aggressive behaviours towards friends, classmates and strangers.

According to another a longitudinal study conducted in the year 1977 by Huesmann and his colleagues, 'Early exposure to T.V violence predicts aggression in adulthood. The study was conducted on the 557 children age from 6- 10 years. In this study it was revealed that early childhood exposure to TV violence predicted aggressive behaviour for both males and females in adulthood.

\section{Media reports on crime and young adults:}

Hindustan times, sep.03.2013, published an article 'Crime shows masking the society a better place'. In this article it was reported that now days there are many crime shows based on crimes which has a good TRP rate and the details of these crime serials helps the viewers to get a peek into criminal minds which helps us to stay alert but long exposure to crime may bring fear of unsafe society. It may bring fear in kids and youngsters.

Tanay (2012) said in psychiatric times that "Whenever you will turn on the television you will find violence, you go to movie and there also you will find violence. Reality is fully distorted and if we will live in a fictional world, then the fictional world become our reality. Thus violence in the media has been increasing and reaching proportions that are dangerous”

\section{Debates on crime and society:}

According to the debate done by Yahoo in (2013) on 'how does the media effect the society'. Debater explains about how media affects society by telling that the influences of television can be seen by looking on that an average American watch over 8 hours of TV a day, 'according to that debater 'media affect how we learn about our world and interact with one another.

According to another debate done on the "does television have a malign influence on society: violence and crime- does TV watching increases crime and violence rate?” in 2013. It has been found that around 56\% of people have given their responses ' $N O$ ' and around 44\% people have said 'YES' it promotes violence and crimes. 
The above discussion shows that few researches have been done on the effect of media on youth violence but none of these studies have been carried out in India.

Thus this area needs lots of research. The present research is only a first step in the direction by the researcher due to paucity of time this research is limited to aggression level of qualitative data based on the findings the researcher plans to take the study further in near future.

\section{METHODOLOGY}

Objectives

(i) To study the effects of crime serial on the level of aggression on young adults.

(ii) To study the effect of crime serial on the level of emotions on young adults.

(iii) To study the attitude towards crime serial.

\section{Variables:}

Independent variable: Crime clips shown to the participants.

Dependent variable: effect on the level of aggression and on various emotions on young adults.

\section{Design of the research:}

In the present study the researcher employed the Pre-test and Post-test design to measure the effect of crime serial on the level of aggression and various emotions on young adults.

\section{Sampling group and sampling procedure:}

In this study non-probability sampling was employed by the researcher and panel of guides. Due to paucity of time incidental sampling was employed in this study. The total 30 female Sample were taken from the Amity University. The students were Graduate and Undergraduate students enrolled in their respective programs.

\section{Measures (Tools):}

Buss and Perry Aggression Questionnaire scale was used to measure the aggression level on youth. This scale was designed by Arnold Buss and Mark Perry in 1992. The aggression questionnaire contains 29 items in which the participants were asked to give the rank to each item on the basis of seven- point Likert-type scale to indicate the extent to which each items describe their aggression. The seven point Likert -type scale ranges from extremely uncharacteristic to me (1) to extremely characteristics to me (7).

The Rating Scale was used to measure the level of emotions in which there are total 8 emotions. The participants were asked to rate each emotions in the rating scale on the basis of five- point Likert-type scale to the extent to which the 8 emotions describe their present feeling. The five point Likert-type scales Range from not at all (1) to very high degree (5). 
Semi- Structure Interview Schedule (SSIS) was used to know about the knowledge regarding the crime serials. The SSIS contains eight open-ended questions related to participants in which they have to response according to their knowledge.

The tools used in the present study were selected for the final study after it was assessed by panel of guides and experts. A small pilot study was conducted in order to test the tools.

\section{Procedure:}

In the present research the researcher has taken the sample of 5 students from Amity University on which the researcher conducted the pilot study. In the pilot study the participants were shown some crime clips and were asked to respond on what emotions they were feeling and on the basis of this pilot study a crime clip was selected according to their response along with the eight emotions which were evoked in most participants. Another tool Buss and Perry Aggression Questionnaire were selected and then a Semi- Structure Interview Schedule was prepared with the help of panel of guides and experts.

Before conducting the research a demographic details were taken from the each participants. Then to know the effect of media violence pre and post Aggression Questionnaire along with the rating scale of emotions was individually administered on the gap of 3 days on the sample of 30 female students age from 18-25.. Following to that an Interview was taken from the participants with the help of Semi-Structure Interview Schedule in which certain questions related to crime serials were asked to respond.

After administering these tools and conduction of the study participants were free to leave their feedback relating to their experience throughout the study.

\section{Data Analysis:}

In this study the researcher calculated the mean of both Pre and Post Aggression Questionnaire then to know whether there is a relation between the pre and post Aggression Questionnaire the t- test was performed. With the help of $t$ - test the researcher found that whether the result is significant or not.

In the rating scales of emotions again the mean was calculated and then to know the whether there is relation between pre and post rating scale of emotions the t-test was performed.

For the Semi-Structure Interview Schedule the researcher with the help of guide content analysis were performed to found the various categories and to know the knowledge of young adults regarding the crime serials. 


\section{DISCUSSION AND INTERPRETATION}

Present research study the level of aggression, various emotions regarding the effects of crime serials and to study about the attitude of young adults by the semi-structure interview schedule regarding crime.

Table 1 Showing Pre and Post-test effect on aggression level

\begin{tabular}{|l|l|l|l|l|l|l|l|l|}
\hline \multicolumn{2}{|l|}{} & Mean & N & $\begin{array}{l}\text { Std. } \\
\text { Deviation }\end{array}$ & $\begin{array}{l}\text { Std. } \\
\text { Error } \\
\text { Mean }\end{array}$ & t & df & Sig. \\
\hline \multirow{4}{*}{ Pair 1 } & pre_physical & 44.7667 & 30 & 8.41871 & $\begin{array}{l}1.5370 \\
4\end{array}$ & & 29 & \\
\cline { 2 - 9 } & post_physical & 41.1333 & 30 & 12.14775 & $\begin{array}{l}2.2178 \\
7\end{array}$ & 1.508 & & NS \\
\hline \multirow{4}{*}{ Pair 2 } & pre_verbal & 19.3333 & 30 & 6.59327 & $\begin{array}{l}1.2037 \\
6\end{array}$ & & 29 & NS \\
\cline { 2 - 9 } & post_verbal & 20.8667 & 30 & 6.30125 & $\begin{array}{l}1.1504 \\
5\end{array}$ & -1.297 & & \\
\cline { 2 - 9 } & pre_angerr & 32.7333 & 30 & 8.19560 & $\begin{array}{l}1.4963 \\
0\end{array}$ & .747 & 29 & NS \\
\hline \multirow{2}{*}{ Pair 4} & post_angerr & 31.5000 & 30 & 8.48020 & $\begin{array}{l}1.5482 \\
7\end{array}$ & & & \\
\cline { 2 - 9 } & pre_hostility & 27.5667 & 30 & 8.95846 & $\begin{array}{l}1.6355 \\
8\end{array}$ & .588 & & NS \\
\hline
\end{tabular}

In the present research after examining the pre and post effect of crime serials on the level of aggression it was found that there was no significant difference in the mean of the pre physical, verbal, anger, and hostility and in the post physical, verbal, anger, hostility. Table 1 show that there is no effect of crime serials on the level of aggression of young adults. One of debate conducted by debate.org also supports the present findings according to the debate.org in 2013 on 'Does the media cause violence' it was found that over $63 \%$ of the population says 'No' media does not cause violence whereas only $37 \%$ population was agree to that media causes violence. Probable reasons behind the findings may be that the sample size taken in the present research was very small i.e. 30 in order to reject the null hypothesis of the present research. Another reason for in significant result was time duration. As during reviewing the literature it was observed that in most of the media violence and aggression is either longitudinal, or has a large sample size. But in this research due to paucity of time duration for crime clip for generating aggression was very less. Another reason is that the sample taken for the present study is homogenous that is only females due to which there are not many differences in responses. Generally males are more aggressive and also the protagonist in most of the crime 
serials including the present clipping. Another possible reason for insignificant result is that the crime clip was very scary, full of thrilled and full of suspense which instead of developing aggression it generates the hatred feeling, sad and disgust feeling.

Table 2 Showing Pre and Post-test effect on emotions

\begin{tabular}{|c|c|c|c|c|c|c|c|c|}
\hline & & Mean & $\mathbf{N}$ & $\begin{array}{l}\text { Std. } \\
\text { Deviation }\end{array}$ & \begin{tabular}{|l} 
Std. \\
Error \\
Mean
\end{tabular} & $\mathbf{t}$ & df & Sig. \\
\hline Dair 1 & pre_fear & 1.5000 & 30 & .93772 & .17120 & -3.395 & 29 & .002 \\
\hline & post_fear & 2.5667 & 30 & 1.30472 & .23821 & & & \\
\hline Dair $?$ & pre_advent & 2.8000 & 30 & 1.24291 & .22692 & 2.088 & 29 & .046 \\
\hline & post_advent & 2.1333 & 30 & 1.38298 & .25250 & & & \\
\hline Pair 3 & pre_hate & 1.7000 & 30 & 1.17884 & .21523 & -3.806 & 29 & .001 \\
\hline & post_hate & 2.9333 & 30 & 1.43679 & .26232 & & & \\
\hline & pre_interested & 3.7333 & 30 & 1.11211 & .20304 & 2.617 & 29 & .014 \\
\hline & post_interested & 3.1000 & 30 & 1.24152 & .22667 & & & \\
\hline Dair 5 & pre_curious & 3.4000 & 30 & 1.27577 & .23292 & .909 & 29 & .371 \\
\hline & post_curious & 3.1667 & 30 & 1.28877 & .23530 & & & \\
\hline Dair 6 & pre_anxiety & 1.9000 & 30 & 1.09387 & .19971 & & & \\
\hline Pall o & post_anxiety & 2.8667 & 30 & 1.30604 & .23845 & -3.293 & 29 & .003 \\
\hline Pair 7 & pre_sad & 1.7667 & 30 & 1.04000 & .18988 & -4.481 & 29 & .000 \\
\hline & post_sad & 3.2667 & 30 & 1.48401 & .27094 & & & \\
\hline & pre_disgust & 1.6000 & 30 & 1.13259 & .20678 & -6.033 & 29 & .000 \\
\hline Pair 8 & post_disgust & 3.2000 & 30 & 1.60602 & .29322 & & & \\
\hline & pre_anger & 1.9333 & 30 & 1.48401 & .27094 & & & \\
\hline Pair 9 & post_anger & 3.7000 & 30 & 1.46570 & .26760 & -5.227 & 29 & .000 \\
\hline & & & & & & & & \\
\hline
\end{tabular}

Pre and Post-test effect on the rating scale of emotions:

After examining the effect of crime serial on the level of various emotions the result shows that in (Table 2) there was a difference between pre and post scores on fear, adventure, hate, interested, curious, anxiety, sad, disgust, anger but there is no significant difference for the emotion pre and post of curious. The crime clip which was shown to the participants were based on the 'serial murder' in which the culprit was a 'Man eater' which brings the emotions like hate, 
fear, anxiety , anger, sadness, disgust, and adventure like emotions while and after watching the crime clip. Another reason is that the female sample size, as females got scared easily, an afraid of horror things than males. According to a study done in 2011 by Galli, Wolpe and Oltten on 'Sex difference in use of anticipation brain activity to encode emotional events' the sample was 30 males and 30 females and the result found was showed that the mere anticipation of something bad was enough to kick women's brain into action- but not males. In this research it was also found that woman got more scared during horror films than man do.

Qualitative study of young attitude through semi- structure interview schedule: In the present study a semi-structure interview schedule was conducted and certain information's regarding crime serials was collected from each participant individually and through content analysis the result were obtained.

Table 3- Showing Reasons for interest in watching crime serial.

\begin{tabular}{|l|l|l|}
\hline \multicolumn{1}{|c|}{ CONTENTS } & TOTAL & PERCENTAGE \\
\hline To know what happens really & 11 & $29.72 \%$ \\
\hline Don't like watching & 7 & $18.91 \%$ \\
\hline $\begin{array}{l}\text { To know result, culprit punishment, } \\
\text { justice and types of crime }\end{array}$ & 6 & $16.2 \%$ \\
\hline $\begin{array}{l}\text { How cases solved, suspense, curiosity } \\
\text { and evils deed }\end{array}$ & 6 & $16.2 \%$ \\
\hline To be alert and updated & 3 & $8.1 \%$ \\
\hline $\begin{array}{l}\text { Miscellaneous (thinking, adventure, } \\
\text { crime laws etc.) }\end{array}$ & 5 & $13.5 \%$ \\
\hline Total & 38 & $100 \%$ \\
\hline
\end{tabular}

With reference to the first question about what makes interest in watching these crime serials the answer from the Table 3 reveals that: $\mathbf{2 9 . 7 2 \%}$ of the participants watch serials in order to know what is happening in reality. According to researcher observation most of the participants were very keen to watch crime serial name 'Nithari Kand' as it was based on reality which was very famous. The most of the participants were interested in watching crime because they are either from psychology background or mass communication background who likes to know what reality behind all these crime is and what is going on criminal minds. $18.91 \%$ of the participants don't like to watch crime serials. The probable reason is that they are students of Amity University where there are lots of pressures for studies due to which they don't get time to watch crime serials. According to researcher observation most of the participants don't like to watch because they are not real and they feel disgusted. $\mathbf{1 6 . 2 \%}$ of the participants like to watch because they want to know the result, about how culprit punishes, justice, about types of crimes and suspense, curiosity evils deed respectively. According to researcher observation the probable reason may be that most of the participants are either of mass media students, law student, or of psychology student and they get to learn through these crime serials about the crime, criminal 
minds etc. 8.1\% of the participants like to watch because they help to be updated and alert. The probable reason may be that the participants most of the participants are living independent life so they always keep themselves updated in order to be safe from becoming victim. $\mathbf{1 3 . 5 \%}$ of the participants watch because they it gives adventure to them, help to know about crime laws and about the thinking of criminal minds. According to researcher observation most of the students are extrovert by their personality and extroverts are most likely to be adventurous (Eysenck \& Eysenck, 1975-1994 extroverts are adventurous in their personality).

Table 4 Showing About how they feel when they read/see crime.

\begin{tabular}{|l|l|l|}
\hline CONTENTS & TOTAL & PERCENTAGE \\
\hline Sad and disgust & 13 & $34.21 \%$ \\
\hline anger & 7 & $18.42 \%$ \\
\hline To punish by rules and laws & 4 & $10.52 \%$ \\
\hline Frustrated and annoyed & 2 & $5.26 \%$ \\
\hline Miscellaneous & 9 & $26.31 \%$ \\
\hline Total & 35 & $100 \%$ \\
\hline
\end{tabular}

With reference to the second question about how they feel when they read/see about crime the answer from the Table 4 reveals that: $\mathbf{3 4 . 2 1 \%}$ of the participants feel sad and disgust when they read or see about crimes. The reason behind the response may be the sample size of present study which was only 30 females and they are more sensitive, they easily get upset, disgust, and sad by these crimes. Another possible reason is that most of the crimes are related to females like rape, assault, harassment, kidnapping, molesting etc which frustrated and annoy females and they feel sad disgust by the crimes. $\mathbf{1 8 . 4 2 \%}$ participants feel anger when they see or read about crimes. The probable reason may be because they are girls and they are more sensitive than males. $\mathbf{1 0 . 5 2 \%}$ and $\mathbf{5 . 2 6 \%}$ participants feel that the culprits should be punished by rules and they feel frustrated annoyed respectively. According to researcher observation most of the crime cases are related to females due to which they feel frustrated and want to live life without any fear so they feel like to punish them and finish them by laws and rules. 26.31\% participant feel worried, terrified and hate while reading and watching about crime. According to researcher observations the possible reason may be that they feel worried of being victimised by the criminals or they may be get attacked by the criminals. 
Table 5 Showing about how they feel after watching these crime serials.

\begin{tabular}{|l|l|l|}
\hline \multicolumn{1}{|c|}{ CONTENTS } & TOTAL & PERCENTAGE \\
\hline Sad and disgust & 14 & $34.14 \%$ \\
\hline Bad, hatred, tensed, worried, pathetic and make fools & 8 & $19.48 \%$ \\
\hline Angry and irritated & 4 & $9.76 \%$ \\
\hline alert & 2 & $4.87 \%$ \\
\hline Miscellaneous (panic, upset, emotional) & 13 & $31.70 \%$ \\
\hline Total & 42 & $100 \%$ \\
\hline
\end{tabular}

With reference to the third question about how they feel after watching these crime serials and the table 5 shows that $\mathbf{3 4 . 1 4 \%}$ of the participants feel sad and disgust after watching these crime serials. The reason behind these responses is may be again as for the above question that is the sample size for this research is 30 females who are more sensitive by emotions. $\mathbf{1 9 . 4 8 \%}$ and $\mathbf{9 . 7 6} \%$ of the participants feel like irritated, tensed, worried, make fools and angry after watching these crime serials. According to researcher observation most of the crime serials are of pathetic as it shows the psychic and sic mind of the criminals. Another possible reason may be that they are not real sometimes and sometimes they show real stories by exaggerating it in a negative way that they feel irritated. $\mathbf{4 . 8 \%}$ of the participants feel alerted. The possible reason may be that it shows about criminal minds, types of crime. $\mathbf{3 1 . 7 0 \%}$ of the participants feel panic, upset and emotional. According to researcher observation the clipping which was shown to the participants were based on man eaters who have murder many children's after raping them and harassing them due to which participants feel upset for their parents and for them. Another reason for panic may be because in thr clip the culprit has eaten the body parts of the children's.

Table 6 Showing you like watching/ reading about crime.

\begin{tabular}{|l|c|c|}
\hline \multicolumn{1}{|c|}{ CONTENTS } & TOTAL & PERCENTAGE \\
\hline Yes (awareness and self-defenses) & 17 & $56.67 \%$ \\
\hline No & 7 & $23.33 \%$ \\
\hline Not much & 6 & $20 \%$ \\
\hline Total & 30 & $100 \%$ \\
\hline
\end{tabular}

With reference to the fourth question about them like watching/ reading about crime and from the table 6 it reveals that: $56.67 \%$ of the participants like to watch and read about crime. The reason behind the responses is that the today's generation due to increasing rate of crime towards woman they want to be more alert and updated. Woman's like to watch these serials in today's scenarios it helps to know about how culprit commit crimes against woman and what to do to be on safer side. According to the researcher main reason behind the responses is that the females 
are becoming more independents in today's life. They want to aware and to be alert. $\mathbf{2 3 . 3 3 \%}$ of the participants don't like to watch or read about crimes. According to researcher observation most of the participants hate watching or reading about crime serials because they feel disgusted and sad as they are not real and they feel that they are cheating them and making fool of them. $\mathbf{2 0 \%}$ of the participants like to watch but not much. The possible reason is may be that they are students and they don't get enough time to watch after studying or they are not very much interested in watching crime serials whole day.

Table 4.7 Showing: Sources of information.

\begin{tabular}{|l|c|c|}
\hline \multicolumn{1}{|c|}{ CONTENTS } & TOTAL & PERCENTAGE \\
\hline Newspapers/TV serials/ news on TV & 28 & $62.22 \%$ \\
\hline Social media & 10 & $21.74 \%$ \\
\hline movies & 2 & $4.44 \%$ \\
\hline Miscellaneous (neighbours, magazines) & 5 & $11.11 \%$ \\
\hline Total & 44 & $100 \%$ \\
\hline
\end{tabular}

With reference to the fifth question about what are the sources for them for information and from the table 7 it shows that: $62.22 \%, 21.74 \%$ and $4.44 \%$ of the participants for them the sources of information regarding crime are from newspaper, television, social media and movies respectively. The reason behind is that young generation likes to be updated and aware about crimes. In today's scenario almost in every family there is at least one TV or computer thus either through social or media or through television news they know about the various crimes. For the $\mathbf{1 1 . 1 1 \%}$ of the participants sources of information are from neighbours, magazines.

Table 8 Showing: Crime serial as a catalyst in increasing crime rate.

\begin{tabular}{|l|c|c|}
\hline \multicolumn{1}{|c|}{ CONTENTS } & TOTAL & PERCENTAGE \\
\hline Yes (to some extent) & 17 & $56.69 \%$ \\
\hline No (they are for awareness) & 8 & $26.67 \%$ \\
\hline May or may not & 5 & $16.67 \%$ \\
\hline Total & 30 & $100 \%$ \\
\hline
\end{tabular}

With reference to the sixth question about that is crime serial are plays as a catalyst in increasing crime rate and Table $\mathbf{4 . 8}$ shows that: $\mathbf{5 6 . 6 9 \%}$ of the participants feel that crime serials plays as a catalyst in increasing crime rate. The main reason behind yes is that according to the Bandura social learning theory people learn things by observing others. Another possible reason may be that crime serials help criminals in providing new ideas of committing crime. $\mathbf{2 6 . 6 7 \%}$ of the participants respond that no it creates awareness rather than increasing crime rate. The reason for the no response is that it depends on the people how they perceive things as they all are aware of what is real and what is fiction. According to Tanay (2012) said in Psychiatric Times that reality is fully distorted and if people live in a fictional world, then the fictional world become our reality. That is why violence in the media has been increasing and reaching proportions that are 
dangerous. $16.67 \%$ of the participants says that it may or may not plays as a role of catalyst in increasing crime rate.

Table 4.9 Showing about awareness of various laws enforced in society.

\begin{tabular}{|l|c|c|}
\hline \multicolumn{1}{|c|}{ CONTENTS } & TOTAL & PERCENTAGE \\
\hline yes & 21 & $70 \%$ \\
\hline Some of them & 6 & $20 \%$ \\
\hline No & 3 & $10 \%$ \\
\hline Total & 30 & $100 \%$ \\
\hline
\end{tabular}

With reference to the seventh question about are they aware of various laws enforced in the society and the answers from the Table 4.9 showing that: $\mathbf{7 0 \%}$ of the participants are aware of the various laws enforced in the society. The reason behind is that the participant $\mathrm{s}$ are from the middle upper background and studying in Amity University where many subjects helps in bringing awareness, knowing about laws. Another reason is may be that the females are becoming more independent and they want to be updated and alert by knowing about various laws, to be on safer side. Another reason is that the most of the participants are pursuing psychology and mass communication courses where to know about various crimes and laws are important. $\mathbf{2 0 \%}$ of the participants are somewhat aware of various laws. $\mathbf{1 0 \%}$ of the participants are not aware of various laws enforced in the society.

Table 4.10 Showing: Do shows teach something other than instigating fear.

\begin{tabular}{|l|c|c|}
\hline \multicolumn{1}{|c|}{ CONTENTS } & TOTAL & PERCENTAGE \\
\hline Yes & 13 & $41.94 \%$ \\
\hline Aware and safe & 11 & $35.48 \%$ \\
\hline Fear & 3 & $9.68 \%$ \\
\hline No & 3 & $9.68 \%$ \\
\hline Total & 30 & $100 \%$ \\
\hline
\end{tabular}

With reference to the eighth question about do serials teach them other than instigating fear and from the Table 4.10 it was revealed that: $41.94 \%$ and $35.48 \%$ of the participants have responded that yes they teach other than something and they make aware, safe respectively. The reason for 'yes' may be because they get to know about laws. It was observed that most of the participants like to watch these serials because they get to know about reality about criminal minds. 9.68\% of the participants has responded each for no and they instigate fear. After obtaining response the possible reason is may be due to the crime clip which were shown to them were very scary and in that case the justice is still awaiting by the parents of victims. Another possible reason may be that the clip shown to them was based on owner killing which is scary. 
REFERENCES

Anderson, C., Berkowitz, L., Donnerstein, E., Huesmann, L., Johnson, J., Linz, D., ...Wartella, E .(2002). The influence of media violence on youth. Psychological Science in the Public Interest4, 81-110. $\quad$ Retrieved March 20, 2015 from http://rcgd.isr.umich.edu/aggr/articles/Huesmann/2003.Anderson_etal.InfluenceofMedia ViolenceonYouth.PsychologicalScienceinthePublicInterest.pdf

Bersein, E. (2014). The impact of media violence on children and adolescents psychiatry. Retrieved March 20, 2015, from http://www.aacap.org/imact-of-media-violence-andchildren-adolescents-opportunities-for-clinical-interventions-american-academy-of-chiladolesents.html

Bushman, B \& Hueshman, R. (2006). Short term and long term effect of violent media on aggression in children and adults: A meta- analysis. Archives of Pediatrics and Adolescent Medicine, 160(4), 348-352. doi:10.1001/archpedi.160.4.348

Chery, K .(2015a). Bobo doll experiment. Bandura famous experiment on aggression. Retrieved March 20, 2015, from http://psychology.about.com/od/classicpsychologystudies/a/bobodoll-experiment.htm

Chery, $\mathrm{K}$.(2015b). What is aggression. Retrieved March 20, 2015, from http://psychology.about.com/od/aindex/g/aggression.htm

Darkheartc, M .(2013). Does television have a malign influence on society: Violence and crime Does TV watching increase crime and violence rates?. Retrieved March 22, 2015 from http://www.debate.org/opinions/does-television-have-a-malign-influence-on-societyviolence-and-crime-does-tv-watching-increase-crime-and-violence-rates

Gail, G., Wolpe, N., Otten, L. (2011). Sex differences in the use of anticipatory brain activity to encode emotional events. The journal of neuroscience, 31(34): 1236412370; doi: 10.1523/JNEUROSCI.1619-11.2011

Huesmann, L., Titus, J., Podolski, C., \& Ero, L. (1977-1992). Longitudinal Relations between Children's Exposure to TV Violence and Their Aggressive and Violent Behavior in Young Adulthood. Development Psychology, 39(2), 201-221. doi: 10.1037/00121649.39.2.201

Kalpan, A. (2012). Violence in the media: What effects on behaviour?. Psychiatric times. Retrieved March 26, 2015. from http://www.psychiatrictimes.com/child-adolescentpsychiatry/violence-media-what-effects-behavior

Kausal, S. (2013). Crime shows making the society a better place. Hindustan times. Retrieved March 19, 2015. from http://www.hindustantimes.com/television/crime-shows-makingthe-society-a-better-place/article1-1116333.aspx

Knoch, K., \& Borbora, J. (2013). Involvement of youth attitudes in crime: A study conducted in four jails of upper Assam, India. American International Journal of Research in Humanities, Arts and Social Sciences, 2(2), 116-121. Retrieved March 24, 2015. from http://iasir.net/AIJRHASSpapers/AIJRHASS13-150.pdf

Krug.G., Dahlberg, L., Mercy, J., Zwi, A., \& Lozano, R. (2015). Youth violence. World report on violence and health, 2, 23-49. Retrieved March 20, 2015. from 
http://www.who.int/violence_injury_prevention/violence/world_report/en/full_en.pdf?ua $=1$

Maclntosh, N. (2014). BBC crime and the law in society. Causes and types of crime. Retrieved March 20, 2015, from www.bbc.co.uk/bitesize/intermediate2/modern-studies/crime-andlaw-in -society/causes-types-crime/revision/1/

Mcdonald, J. (2015). Neighbourhood effects on crime and youth violence. Retrieved from March 20, 2015. from http://www.rand.org/pubs/technical_reports/TR622.html

Ministry of Home Affairs. (2015). Raising Crime in Indian Cities. Retrieved March 20, 2015. from https://fightagainstcrime.wordpress.com/tag/national-crime-record-bureau/

Paik, H., \& Cornstock, G. (1994). The effects of television violence on antisocial behaviour: 9 Meta- analyses. Communication research, 21(4), 516-546.

doi: 10.1177/009365094021004004

Peterson, S.(2015). Top 25 crimes, offenses and violations. $11^{\text {th }}$ Global Youth Justice Training. Retrieved March 22, 2015.from http://www.globalyouthjustice.org/TOP_25_CRIMES.html

Sanson, A., Duck, J., Cupit, G., Ungerer, J., Scuderi, C., \& Sutton, J. (2000). Media representing and responsibilities. Australian Psychological Society. Retrieved March 20, 2015. from http://public.psych.iastate.edu/caa/VGVpolicyDocs/00AustrPsySocMV.pdf

Shelar, N .(2010). Definition of crime. Meeting of minds. Retrieved March 20, 2015. fromhttp://likemindness.blogspot.in/2010/11/Definitio-of-Crime.html

Shoener, N. (2014). What are the different types of crimes?. Legal match. Retrieved March 10, 2015 from http://www.legalmatch.com/law-library/article/what-are-the-different-typesof-crimes.html

Slotsve, T., Carmen, A., Sarver, M., \& Wtkins, R. (2008). Television violence and aggression- A retrospective study. The Southwest Journal of Criminal Justice, 5(1). 22-49. Retrieved March 20, 2015. from http://swacj.org/swjcj/archives/5.1/4\%20Slotsve.pdf

Ta, J. (2014). What impact has social media truly on society?. Score Orange County. Retrieved March 30, 2015. from http://scoreoc.org/2014/07/30/impact-social-media-truly-society/

Witmer, D. (2015). Causes of youth violence. About Parenting. Retrieved March 22, 2015. from http://parentingteens.about.com/od/youthviolence/tp/Causes-of-Youth-Violence.htm 